Omni-Akuatika 12 (2): 130-136, 2016
ISSN: 1858-3873 print / 2476-9347 online
Research Article

\title{
Nike (Awaous melanocephalus) Fishery and Mercury Contamination in the Estuary of Bone- Bolango River
}

\author{
Aziz Salam, Femy M. Sahami, Citra Panigoro \\ Department of Aquatic Resources Management, Faculty of Fisheries and Marine Science, \\ State University of Gorontalo, Jl. Jend. Sudirman No.6, Gorontalo 96128, Indonesia
}

Corresponding author: aziz_salam@ung.ac.id

\begin{abstract}
Nike fish (Awaous melanocephalus) is a tiny-kind of fish harvested lunar-monthly in the estuary of BoneBolango River in the City of Gorontalo. The fishing activity is showing steady increase recently as the commodity finds its way to the international market. Fishermen are putting more efforts by escalating the catching capacity of their gears. Meanwhile, mercury used by the artisanal and small-scale gold mining (ASGM) in the headwaters for amalgamation put another aspect to the $A$. melanocephalus fishery when it wasted into the river down to the estuary. This paper describes $A$. melanocephalus fishery and the threat of mercury contamination in the habitat and the fish itself. Field research was conducted in the estuary of Bone-Bolango River to observe the technology and methods of $A$. melanocephalus fishing. Samples of water and fish were taken for mercury content examination with Atomic Absorption Spectrophotometer (AAS). Secondary data on production and distribution were obtained from government offices. The result showed that the water and $A$. melanocephalus samples contain mercury at levels exceeding the quality standards determined by government.
\end{abstract}

Keywords: nike, mercury, food security, sustainable fishery

\section{Introduction}

Nike, (pronounced: nee-K) fish or scientifically known as Awaous melanocephalus seems to have become part of the cultural fabric of society in Gorontalo since the ancient time and perhaps one of the key factors that enable the early development of civilization in this northern part of Tomini Gulf. According to the myth that tries to explain its origin, the fish is the incarnation of an ancestor's menstrual blood spilled into the river. Elders have proven the 'evidence' of this story by eye witnessing balls of membrane of coconut size with larvae enclosed in it, drifted from the headwaters to the river mouth and hatched as the membrane explode into a schooling of juvenile fish.

After becoming the capital of Gorontalo Province in 2001, Gorontalo City grows rapidly. The growth ultimately brings about a diversity of menus into the ever growing food business as well. Nonetheless, varieties of nike dishes often presented as typical culinary icon become widely renown. In the other hand, its role as important and favorite source of protein may be put under threat from the aspects of food safety and sustainable fishery.

Artisanal and small scale gold mining in Gorontalo has existed since the 1970s (Arifin et al. 2013). The use of mercury as amalgam with uncontrolled discharge into the river poses high risk of contamination and has been a concern of environment nowadays (Balihristi, 2013). Wang et al. (2004) show that one of the most important anthropogenic sources of mercury pollution in aquatic systems is mining. The mining activities in the upper reaches of Bone-Bolango River certainly have impacts on water conditions and organisms in the river and estuary, and eventually to humans who use and consume the water and living organisms. The organic mercury accumulates in the food chain (Jernelov and Lann, 1971) and flows through the blood brain barrier after ingestion by human (Clarkson, 1997; Wolfe et.al. 1998). It has been causing various neurological effects on human. The threat of inorganic mercury is severe because it is more nephrotoxic (Blum, et.al. 2013; Wei et.al. 2014). These are serious threats to human health, in terms of food safety.

Increasing inter-island market demand offers a better economy and stimulates fishermen to increase the catch by increasing capacity of their fishing gear. The fishing gears and methods of fishing have greatly reduced the chances of the fish to migrate back upstream and continue its life cycle. Therefore, declination and even extinction of $A$. melanocephalus population due to over fishing is a reasonable fear and a real threat in the near future. This article describes $A$. 
melanocephalus fishery and the threat of mercury contamination in the habitat and the fish itself.

\section{Materials and Methods}

Study on $A$. melanocephalus is extremely limited. Results of in-depth research about Nike fish cannot be found in scientific journals except for a few that discusses some peripheral aspects about quality, preservation, and processing. Field research was conducted in the estuary of BoneBolango River (Fig. 1) to observe the technology and methods of Nike fishing. Water samples were taken at three stations in April to November 2014 for examination. Station 1 is at the river at $\mathrm{N}$ $00^{\circ} 31^{\prime} 33.5^{\prime \prime}$; E $123^{\circ} 03^{\prime} 50.1^{\prime \prime}$. Station 2 is on the

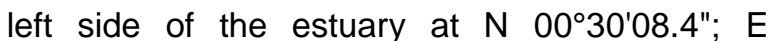
$123^{\circ} 03^{\prime} 54.5^{\prime \prime}$ in front of Leato Village, and Station

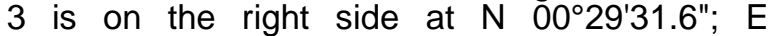
$123^{\circ} 02^{\prime} 40.9^{\prime \prime}$. Both Station 2 and 3 are nike fishing grounds. Nike samples were taken from fishermen catch on fishing site only at Station 2 in two Nike seasons, i.e. the ends of lunar months Jumadil Akhir $\left(26^{\text {th }}\right.$ to $28^{\text {th }}$ of April 2014) and Rajab $\left(27^{\text {th }}\right.$ to $29^{\text {th }}$ of May 2014). Mercury content examination of water and nike samples were done with Atomic Absorption Spectrophotometer (AAS) variant of $0.5-1000 \mathrm{mg} . \mathrm{L}^{-1}$ which has a wave length of $283,3 \mathrm{~nm}$ and a slit width of 0.5 $\mathrm{nm}$ which was calibrated before use. Secondary data on production and distribution were obtained from the office of fish quarantine in Gorontalo City.

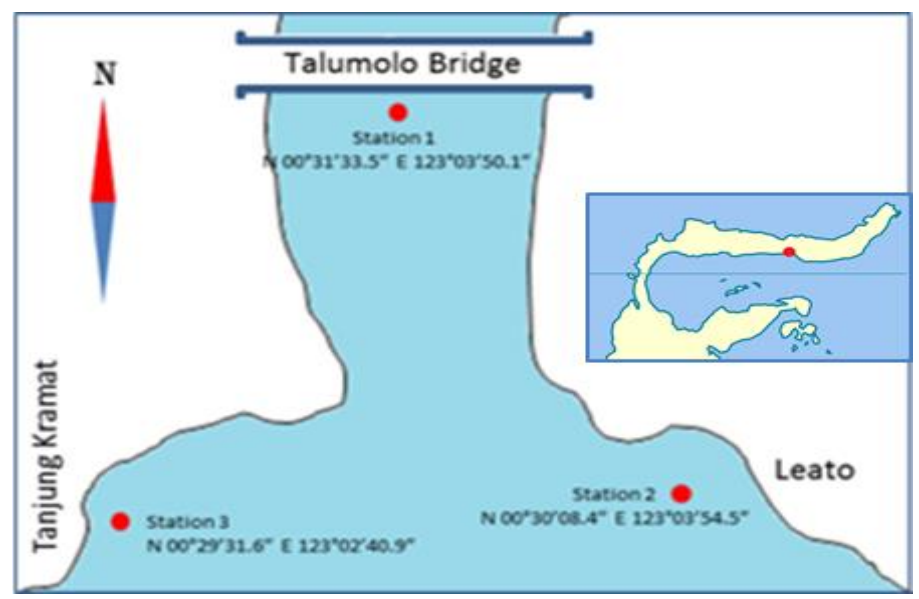

Figure 1. Research site: estuary of Bone-Bolango River.

\section{Results and Discussion}

\section{Nike fishery}

According to Saanin (1984), Nike fish is classified in Class Pisces; Sub-class Teleostei; Ordo Gobiidaea; Family Gobiidae; Genus Awaous; Species A. melanocephalus Bleeker. It has transparent, colorless, and scale-less body of $2.5-3 \mathrm{~cm}$ length and $3-5 \mathrm{~mm}$ depth. Its larvae drift from upstream to the river mouth and hatch in the sea to form juvenile schoolings. Fish caught at juvenile stage in the last ten days of lunar calendar and the schooling is of $99 \%$ juvenile of $A$. melanocephalus and the rest is juvenile of Eleotrisfrusca (Yusuf, 2011). The juvenile nike migrate or return back to the river of their origin at the end of each capture season before the new moon rises.

In Gorontalo Province, schools of nike are found in certain estuaries (Fig. 2), which is called milango in the local language. At least there are four estuaries: Milango Taludaa, Milango Hulondalo, Milango Paguyaman, and Milango Marisa. Milango Hulondalo which is the BoneBolango River's estuary in Gorontalo City has the biggest and steadiest stock. 


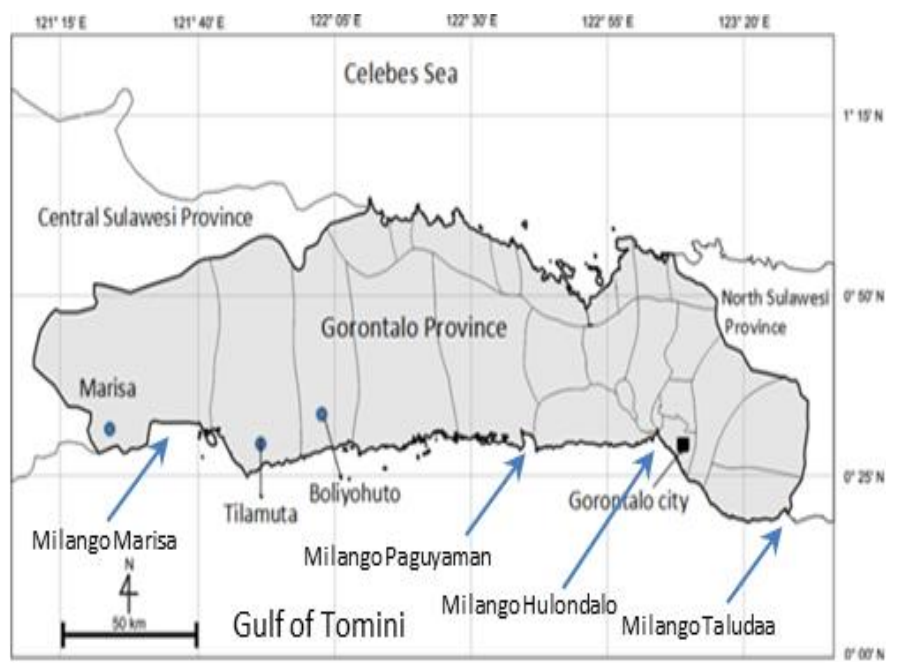

Figure 2. Habitats of nike in Gorontalo Province

Generally, fresh catch sold by itinerant vendors without proper handling to maintain quality. Without preservation the fish can only stay fresh for 2-3 hours. Stock to be sold the next day preserved with low temperature using cold water to maintain freshness. Nevertheless, its quality degraded and the price declines. The fish has a pale appearance due to physical stress during handling and delays in handling. Cooling treatment using insulated cool box with a ratio of bulk ice and nike 1:2 can extend selling period to 10 hours and for ratio $1: 1$ can extend to 20 hours (Panai, 2013). Nike is consumed freshly and cooked for dishes such as nugget, yilepao (sago mixed with nike), pepes nike (grilled in banana leaf), and stir-fry. Dried nike is processed with traditional way by people (Tuina, 2013). Kadir (2008) showed differences in levels of protein contents in nike that caught in the first day and that of the last day. The protein content in the first day $A$. melanocephalus is $2.73 \%$, while in the last day Nike is $4.08 \%$. Nike is known to contain essential amino acids like leucine $(1.15 \%)$ and lysine $(0.84 \%)$, also contains DHA (14.81\%) and oleic acid (8.5\%) (Yusuf, 2011).

There are several kinds of tools and methods used to capture $A$. melanocephalus and improvements have been done to improve the fishing gears. When nike is abundant in the waters and gathers in the shallow rocks, the fish is caught easily with hand or a simple hand net. $\mathrm{A}$ handy triangle lift-net made of two arms of bamboo frames called dudayahu is used for bigger catch. Dudayahu is put in shallow water by laying the net to the bottom with stone sinkers while the bamboo frames stay afloat. Light is placed on the frame when operates at night (Fig. 3a). Dudayahu can also operate on a small canoe by one or two fishermen, a petromax usually used for lighting (Fig. 3b)

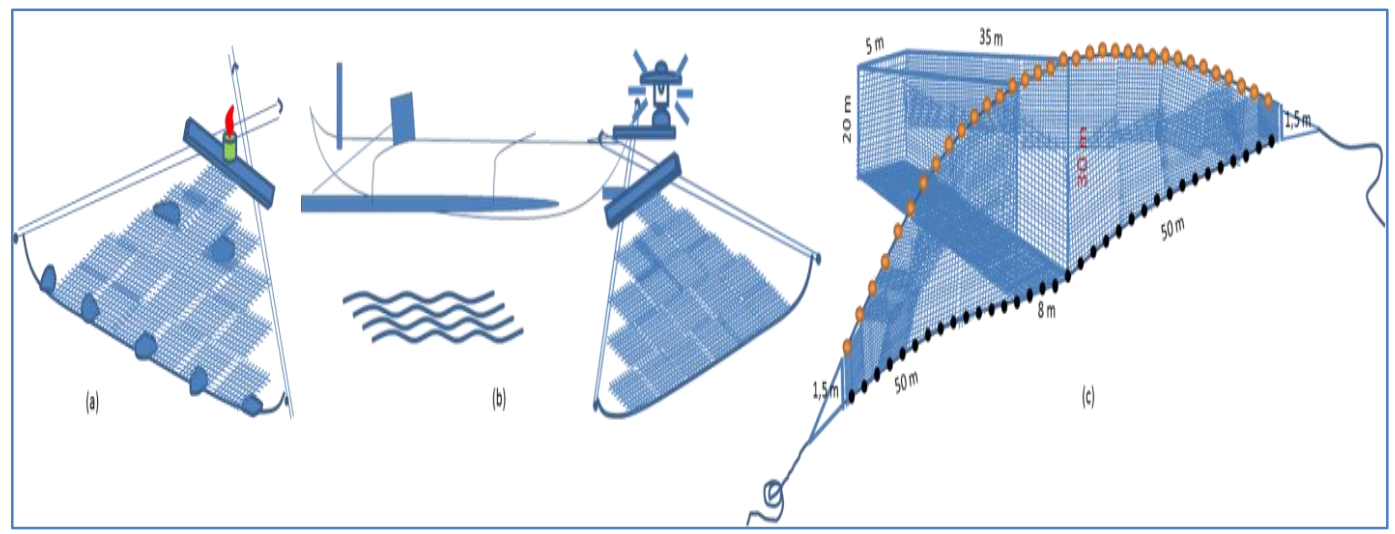

Figure 3. Fishing gears to capture Nike fish 
Larger fishing gear called Tagahu which is a kind of pocket trawl with a very fine mesh that operates on shallow waters by two fishing boats and can also operate from shore line like a beach seine by circling and bracketing capture technique. At night operation, another boat for lighting is used to attract $A$. melanocephalus to schools in front of the net. One or two boats herding the fish to enter the pocket while the trawl is hauled slowly to shrink the space until the schooling stuck in. The two boats at either end of the fishing gear haul the bottom straps line to pull the net from opposite directions so that the two boats get closer and finally raised the pocket and collect the catch.

Size and thus catching capacity of Tagahu has been increasing lately. The smaller Tagahu that operates in waters of a depth of human knee and the middle size that operates in waters up to $15 \mathrm{~m}$ depth now are exceeded by that operates with bigger boats at depths beyond (Fig. 3c). Attempt of fishermen to increase their catching capacity follows the increasing inter-island demand and domestic consumption.

According to a report released by Marine and Fishery Office of Gorontalo Province in 2011, nike production in the year 2009 was 181 tons. Since Nike fish enters the inter-island marketing, production and distribution fluctuate in the last seven years. Based on distribution data from Fish Quarantine Station (Data not shown), commodity of Nike fish shipped inter-island increased in 2010 and during six years there is fluctuation in stock, the value was maximum in 2013 and then continue to decline until September 2016. The last four years declination that shows exponential trend, while demand remains constant, may be interpreted as a signal to stock depletion due to decrease in the ability of the species to regenerate as direct result of excessive capture.

\section{Mercury contamination}

Mercury contamination is found in the water of $A$. melanocephalus's habitat and in the fish itself. Therefore, this research attempted to have a clear figure on mercury contents in the water and the Nike fish.

\section{Mercury concentration in water}

When compared with the standard value of mercury $(\mathrm{Hg})$ maximum levels allowed under Government Regulation No. 82-2001 on the Management of Water Quality and Water Pollution Control and the Decree of Ministry of Environment No. 51-2004 that levels of $\mathrm{Hg}$ that is allowed is $0,001 \mathrm{mg} / \mathrm{l}$. The levels of $\mathrm{Hg}$ in the waters around the mouth of Bone-Bolango River (Station 1) at low tide already exceed the maximum limit of contamination, especially at the riverbed (Fig. 4). At high tide levels of $\mathrm{Hg}$ either at the surface or at the riverbed are still in good condition as the body of water of the river formed by water that comes from the sea, while at low tide the water in the river is mostly coming from upstream.

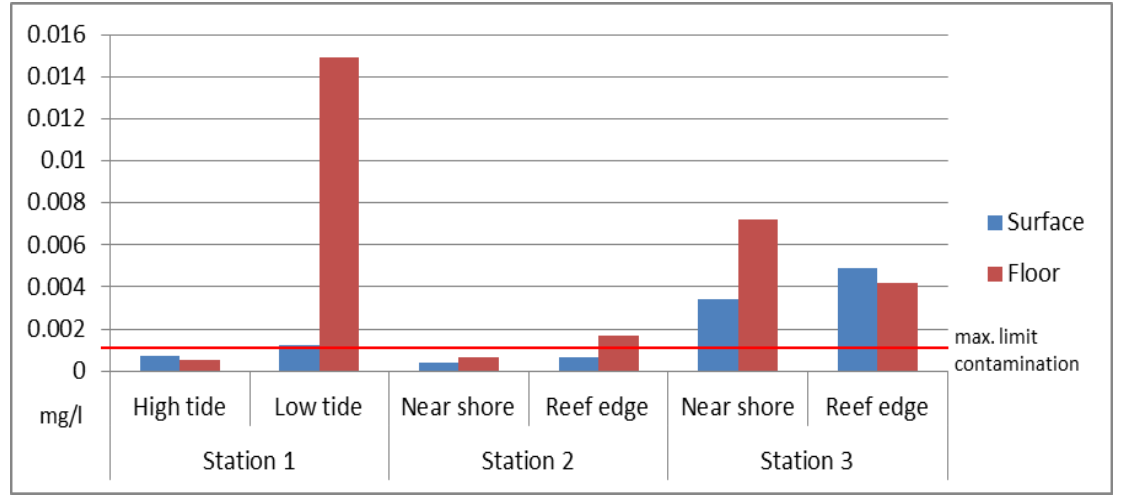

Figure 4. Mercury contamination in water 
The content of $\mathrm{Hg}$ at $A$. melanocephalus fishing grounds (Stations 2 and 3 ) varies in waters near shore and at the reef edge. At Station 2 sub-station near shore levels of $\mathrm{Hg}$ in the surface and the sea floor still far below the maximum limit. At Station 2 sub-station near the reef edge levels of $\mathrm{Hg}$ in surface waters is still far below the maximum limit, but in the bottom waters the content is a little above the limit. Therefore, waters of the $A$. melanocephalus fishing ground at near shore of Leato Village is not categorized as contaminated waters either on the surface as well as the bottom. While the bottom waters near the reef edge are categorized as contaminated waters.

Results of measurements of the levels of $\mathrm{Hg}$ at Station 3 in the sub-station near shore at surface and the bottom of the waters are above the maximum limit. In the sub-station near the reef edge at the surface and bottom waters are four times greater than the maximum limit. Based on this, it can be said that the condition of the waters in the fishing area in Tanjung Kramat Village is contaminated by the heavy metals mercury. These results are higher when compared to a similar study conducted at other areas in Indonesia. As performed by Edward (2008) in the waters of the Gulf of Kao, results of mercury contamination measurements was only about $0.001 \mathrm{mg} \cdot \mathrm{L}^{-1}$.

According to Palar (2008) the presence of metals in the body of water may come from natural sources and from activities undertaken by humans such as household and industrial waste discharges; in addition it may come from the subsided metal particles in the air due to the rain. Darmono (2001) in Triyani (2009) suggest that mercury contamination in Sepauk River West
Kalimantan was likely caused by gold mining activities carried on upstream. This seems to be the case also in Bone-Bolango River. Data resulted from this research suggests that mercury release from gold mining activities conducted by local miners has caused negative effect on water quality. Artisanal and Small-scale Gold Mining (ASGM) activities in Gorontalo Province are reported in Mallongi, et. al. (2014). There are many ASGM sites in Gorontalo Province that mainly using mercury to amalgamate gold from host rock. Mercury contamination to the environment due to ASGM activities in Indonesia were reported in Bose-O'Reilly et.al. (2010) and Castilhos et.al. (2006).

Supriharyono (2007) states that the levels of heavy metals in fish and plants in a contaminated waters could reach 100,000 times higher than the levels of heavy metals in the water itself. Research results reported by Diniah (1995) in Simange, et. al. (2010) has proved this, where the waters of Jakarta Bay's Hg levels was $0.002 \mathrm{mg} \cdot \mathrm{L}^{-1}$ and in the flesh of fish reached 0.80 $\mathrm{mg} \cdot \mathrm{L}^{-1}$. Chemicals in the water are absorbed by organisms through the process of bioconcentration, bio-accumulation and biomagnification, so the concentration of chemicals increase in the body of organisms compared to the water itself (Connell and Miller 1984; Rand and Petrocelli 1985 in Simange, et al. (2010).

\section{Mercury concentration in nike}

A. melanocephalus samples were taken insitu at Station 2 at two different sub-stations: near the shoreline and near the reef edge where they are captured.

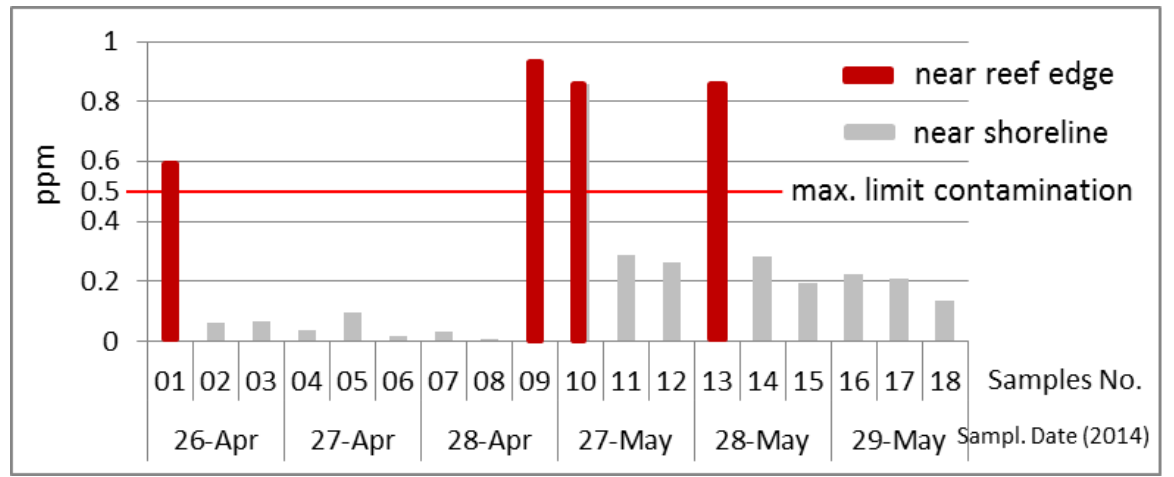

Figure 5. Mercury contamination in nake captured in Station 2 near reef edge and near shoreline. 
High mercury levels are found in four samples taken on April 26 (sample no.01: 0.59 mg. $\mathrm{L}^{-1}$ ) and April 28 (sample no.09: $0.94 \mathrm{mg} \cdot \mathrm{L}^{-1}$ ), and May 27 (sample no.10: $0.86 \mathrm{mg}^{-\mathrm{L}^{-1}}$ ) and May 28 (sample no.13: $0.86 \mathrm{mg}^{-\mathrm{L}^{-1}}$ ) of the eighteen samples taken within six days (Fig. 5). This illustrates that the levels of mercury in nike is not influenced by date of capture and duration of submerged in water. Content of mercury is not uniformly in all samples. Of the three samples taken on the same date when high contamination occurs there is only one sample has high mercury content.

The high level of mercury contamination seems to be strongly related to the spot where nike is captured. Samples with high mercury level are those taken at near the reef edge, contaminated far exceeding the maximum limit contamination of mercury in food permitted by the Indonesia National Standard (SNI 7387:2009) which is $0.5 \mathrm{ppm}$. Samples taken near the shoreline are all at low level of contaminations.

What causes high levels of mercury in the nike captured near the reef edge is still poorly understood. Content of mercury in the water samples taken at the sea floor near the reef edge at the Nike fishing ground in Leato is $0.002 \mathrm{mg} / \mathrm{l}$, way higher than those of other spots in the same station and exceeding the water quality standard which permits only $0.001 \mathrm{mg} / \mathrm{l}$ as imposed by the decree of the ministry of environment (KEPMENLH No.51, 2004). This seems to provide some reason on why the mercury content in the samples taken near the reef edge are higher. Heavy metal like mercury tends to bind organic matters and subsides to the sea floor along with sediment therefore heavy metals content is higher in the water at the sea floor compare with heavy metal content in surface water. According to Palar (2008) mercury gets into fish through respiration, digestion or skin penetration. Mercury that enters organism cannot be digested and it dissolves in fat therefore it can penetrate cell membrane and accumulate at cells in the organs of the organisms.

\section{Conclusion and Suggestion}

Improving catching capacity of nike fishing gears may boost productivity and increase fishermen's income but threat the sustainability of nike fishery if proper measure is not taken. Excessive catch of nike will reduce the chance of the fish to complete their lifecycle thus deplete nike stock over time. The increasing inter-island demand on nike has to be answered wisely by considering sustainability.

Mercury contamination in the water and nike brings about a concern on food safety. The threat will become apparent in near future and the issue will extend to the level of food security as mercury contaminant accumulate excessively in other marine biota consumed by human, spread to staple plants in the watershed of BoneBolango River, and permeate in drinking water supply of the surrounding cities.

Extensive and in-depth research on nike is necessary to address the issue of food safety and the sustainability of nike fishery. Comprehensive understanding on nike in Gorontalo can also apply to the problems of other similar species nationwide.

\section{References}

Arifin, Y.A., Sakakibara, M., Sera, K. 2013. Impacts of Artisanal and Small-Scale Gold Mining (ASGM) on Environment and Human Health of Gorontalo Utara Regency, Gorontalo Province, Indonesia. Geosciences 5(2) : 160-176.

Balihristi. 2013. Status Lingkungan Hidup Daerah Provinsi GorontaloTahun 2013. Badan Lingkungan Hidup, RisetdanTeknologilnformasi (BALIHRISTI) ProvinsiGorontalo.

Blum, J. D., Popp, B.N., Drazen, J.C., Choy, A.C., Johnson, M.W. 2013. Methylmercury Production below the Mixed Layer in the North Pacific Ocean. Nature Geoscience 6: 879-884.

Bose-O'Reilly, S., Drasch, G., Beinhoff, C., Rodrigues-Filho, S., Roider, G., Lettmeier, B., Maydl, A., Maydl, S., and Siebert, U. 2010. "Health assessment of artisanal gold miners in Indonesia". Science of The Total Environment 208: 713-725.

Castilhos, Z.C., Rodrigues-Filho's., Rodrigues, A.P.C., Villas-Boas, R.C., Veiga, M., Beihoff, C. 2006. Mercury Contamination in fish from gold mining areas in Indonesia and human health risk assessment. Science of The Total Environment 368: 320-325.

Clarkson, T. W. 1997. The Toxicology of Mercury. Critical Reviews in Clinical Laboratory Sciences 34: 369 - 403. 
Edward. 2008. Pengamatan Kadar Merkuri (Hg) Di PerairanTeluk Kao (Halmahera) dan Perairan Anggai (Pulau Obi) Maluku Utara. Makara, Sains 12 (2): 97-101.

Jernelov, A., Lann, H. 1971. Mercury accumulation in food chains. Oikos 22 (3): 403-406.

Kadir, N.A. 2008. Analisis Protein Ikan Nike Asal Gorontalo. Skripsi. UNG. Gorontalo.

KEPMENLH No.51. 2004. Baku Mutu Air Laut. Kementerian Lingkungan Hidup Republik Indonesia.

Mallongi, M., Pataranawatt, P., Parkpian P. 2014. Mercury Emission from Artisanal Buladu Gold Mine and Its Bioaccumulation in Rice Grains, Gorontalo Province, Indonesia. Advance Materials Research 931-932: 744-748.

Palar, H. 2008. Pencemaran dan Toksikologi Logam Berat. Jakarta. PT. Rineka Cipta.

Panai, A.S., Sulistyowati, R., Dali, F.A. 2013. Penentuan Perbandingan Es-curahdan Ikan Nike (Awaous melanocephalus) Segar dalam Cool-box Berinsulasi terhadap Mutu Organoleptik dan Mikrobiologis selama Pemasaran. Nikè: Jurnal IImiah Perikanan dan Kelautan 1 (2): 59-64.

Saanin, H. 1984. Taksonomi dan Kunci Identifikasi Ikan. Jilid 1 dan 2. Bina Cipta, Jakarta.

Simange, M. S, Simbolon, D., Jusadi, D. 2010. Analisis Kandungan Merkuri $(\mathrm{Hg})$ dan
Sianida (CN) Pada Beberapa Jenis Ikan Hasil Tangkapan Nelayan di Teluk Kao, Halmahera Utara. IPB. Bogor

Supriharyono. 2007. Konservasi Ekosistem Sumberdaya Hayati di Wilayah Pesisir dan Laut Tropis. Pustaka Pelajar. Yogyakarta

Triyani, A. 2009. Kandungan Merkuri pada Air dan Akumulasinya pada Daging Ikan Patik (Mystus micracanthus Bleeker) di Sungai Sepauk Kalimantan Barat. Skripsi. Fakultas Teknobiologi. Universitas Atma Jaya Yogyakarta. Yogyakarta.

Tuina, F., Naiu, A.S., Yusuf, N.F. 2013. Penentuan Lama Pengeringan dan Laju Perubahan Mutu Nike (Awaous melanocephalus) Kering. Nikè:Jurnal Ilmiah Perikanan dan Kelautan 1 (2): 95102.

Wang, Q., Kim, D., Dionysiou, D.D., Sorial, G.A., Timberlake, D. Sources and remediation for mercury contamination in aquatic systems-a literature review. Environmental Pollution 131 (2): 323-336.

Wolfe, M.F., Schwarzbach, S. Sulaiman, R. A. 1998. Effects of Mercury on Wildlife: A Comprehensive Review. Environmental Toxicology Chemistry 17: 146 - 160 .

Yusuf, N. 2011. Karakterisasi Gizi Dan Pendugaan Umur Simpan Savory Chips Ikan Nike (Awaous melanocephalus). Tesis. Institut Pertanian Bogor. Bogor. 